Mitsuyo Wada-Marciano, Japanese $\mathrm{C} i$ nema in the Digital Age, University of Hawaii Press, Honolulu 2012

\title{
Kino Nipponu przełomu cyfrowego
}

\begin{abstract}
Bochniarz Marek, Kino Nipponu przełomu cyfrowego [Nippon Cinema at the digital turning point]. „Przestrzenie Teorii" 22. Poznań 2014, Adam Mickiewicz University Press, pp. 287-291. ISBN 978-83-232-27-28-1. ISSN 1644-6763.
\end{abstract}

This article is a review of a book written by Mitsuyo Wada Marciano - Japanese Cinema in the Digital Age. The author of this book examines the recent developments in the Japanese film industry at the turning point in the development of digital technologies. The book seeks to overcome the western approach to the subject, reinterprets classic films and explores new trends in transnational Japanese cinema (the term was proposed by the author to explain the situation of Japanese films in the context of Asian countries).

Relatywnie niewielkie kinematografie o zaskakująco wyraźnej sile oddziaływania to twory paradoksalne, wymuszające swoją specyfiką badania odmienne od tych, które podejmuje się na przykład w odniesieniu do kina amerykańskiego. Książka Japanese Cinema in the Digital Age jest więc wyczerpującym raportem Mitsuyo Wady-Marciano na temat funkcjonowania peryferyjnego - z punktu widzenia europocentrycznego modelu świata - przemysłu filmowego, ograniczonego niezbyt imponującymi możliwościami finansowymi, przemysłu, który dość zaskakująco znalazł się jednak na przełomie wieków wśród kin narodowych o światowym rozgłosie (dodajmy, że stało się tak po raz pierwszy od stu lat). Trudno wymieniać w tym miejscu wszystkie przyczyny zaskakującej transformacji japońskiego przemysłu rozrywkowego. Spośród najważniejszych czynników warunkujących stan, w którym kinematografia Nipponu, uznawana dotąd za kino narodowe, przekształciła się w twór transnarodowy o stale rosnącej sferze oddziaływania, warto wymienić nową sytuację polityczno-społeczną w regionie państw dalekowschodnich (wśród których Japonia zajmowała do lat 90 . pozycję kraju kulturalnie „wykluczonego"), a także przełom cyfrowy w historii samego kina.

Punkt zwrotny w kinematografii, jakim była zmiana analogowych nośników filmu na zapis cyfrowy, to ważki, acz trudny temat, podjęty między innymi w filmie dokumentalnym Side by Side (reż. Christopher Kenneally, 2012), w którym rozmówcy - czołowi twórcy Hollywood - za- 
stanawiają się, czy ze zmianą technologiczną nie wiąże się przypadkiem koniec samego kina, a przynajmniej $\mathrm{w}$ takim kształcie, jaki jest nam dzisiaj znany. Model przemysłu, w jakim taśma filmowa $35 \mathrm{~mm}$ powoli staje się reliktem przeszłości, wymaga od filmoznawców rozpoznania i uwzględnienia nowych relacji panujących wśród mediów audiowizualnych. Wada-Marciano opisuje, jak związana $\mathrm{z}$ digitalizacją rewolucja technologiczna wpłynęła na zmianę działalności samych japońskich studiów filmowych i reżyserów na poziomach produkcji i dystrybucji. Studia, których głównym zadaniem w epoce analogowej była produkcja, obecnie zaangażowane są przede wszystkim w dystrybucję filmów w mediach cyfrowych. Z tego powodu doszło do sytuacji charakteryzującej się sprzecznościami, gdyż - jak pisze autorka - „[...] większość reżyserów stała się paradoksalnie niezależna jako filmowcy, lecz coraz bardziej zależna od finansowania i multimedialnej dystrybucji przez główne studia filmowe" (s. 30). Różne kanały, za pomocą których widz może zapoznać się z danym dziełem, związane $\mathrm{z}$ nimi medioznawcze rozróżnienie pomiędzy filmem i DVD, jest obecne także w japońskiej praktyce językowej. Oglądanie filmu (eiga) jest jednoznacznie identyfikowane przez użytkownika języka z projekcją w kinie (eigakan). W przypadku seansu domowego Japończyk nie ogląda filmu, lecz telewizję, VHS, DVD, korzysta się z transmisji strumieniowych itd. Nie tak bardzo ważny jest tu fizyczny materiał (Japonię XXI wieku zdominowały kompleksy kinowe o niewielkich salach, w których odbywają się już prawie wyłącznie projekcje cyfrowe), lecz na pierwszy plan wysuwa się specyfika samego seansu (kinowego i grupowego lub domowego i osobistego), warunkująca inny typ odbioru.

Podejście Wady-Marciano, która uważa, iż o kinie trzeba pisać jako o przemyśle, zwracając uwagę na jego uwarunkowania geopolityczne, historyczne i społeczne, jest zbieżne $\mathrm{z}$ refleksją niemieckiego medioznawczy Wernera Faulsticha, proponującego traktowanie filmu jako produktu z wszystkim tego konsekwencjami. Z tego powodu badaczka krytycznie oceniła pracę Toma Mesa i Jaspera Sharpa ${ }^{1}$, w której autorzy opisali działalność wybranych przez siebie twórców filmowych stosując anachroniczne rozgraniczenie na uprawiających sztukę wybitnych artystów oraz rzemieślników, ograniczonych przez przemysł filmowych. Stąd Japanese Cinema in the Digital Age nie można traktować jako kolejnej publikacji popularnonaukowej w rodzaju katalogów dzieł, które czytelnik powinien zobaczyć ${ }^{2}$.

1 T. Mes, J. Sharp, The Midnight Eye Guide to New Japanese Film, Berkeley 2005.

2 Promowanie japońskiego kina na Zachodzie podczas imprez kulturalnych wiąże się najczęściej z dość tendencyjnym wyborem produkcji. Jako przykład można podać program 
Mitsuyo Wada-Marciano rezygnuje więc z prób tworzenia list filmowych autorów, mistrzów sztuki, uzupełnionych o wykazy ich najważniejszych arcydzieł. Takie praktyki są związane z pewnym ryzykiem, zwłaszcza w przypadku zachodnich filmoznawców, opierających się na już istniejących kanonach kinematografii japońskiej. Są to przeważnie kanony tworzone na podstawie produkcji prezentowanych na międzynarodowych festiwalach. Jednak wiele spośród słynnych, krajowych hitów z czasów, gdy japońskie studia filmowe nie były zainteresowane dystrybucją zagraniczną swoich produkcji, do dziś jest znana głównie wśród samych Japończyków ${ }^{3}$. Pozostaje pytaniem pod rozwagę, w jakim stopniu twórczość Yasujirō Ozu byłaby opisana przez zachodnich badaczy w sytuacji, gdyby mistrz podzielił losy swojego asystenta Minoru Shibuyi, odpowiedzialnego za realizację ostatniego projektu Ozu Rzodkiewki $i$ marchewki (Daikon to ninjin, 1965), którego twórczość jest ceniona w Japonii, lecz, ze względu na brak dystrybucji międzynarodowej, pozostaje zupełnie nieznana poza jej granicami.

Rezygnacja z omawiania kanonów arcydzieł przez autorkę powoduje, że czytelnik Japanese Cinema in the Digital Age zostaje zapoznany z dziełami pośledniejszymi czy produkcjami, które są mu nieznane, a także nadal rzadko bądź wcale nie są obecne w refleksji zachodnich filmoznawców. Dość humorystycznymi ustępami książki są zwłaszcza te, w których Wada-Marciano demaskuje ignorancję swoich kolegów piszących o kinie Nipponu z europocentrycznej perspektywy badawczej. Za przykład może posłużyć opisany przez nią przypadek filmu Kanety Shindō Kobieta-diabet (Onibaba, 1964), który - gdy trafił do dystrybucji DVD w USA i Kanadzie - został opatrzony etykietą horroru i był analizowany z perspektywy tego gatunku (m.in. przez Jyotsnę Kapur ${ }^{4}$ i Adama Lowensteina ${ }^{5}$ ). Wada-Marciano przywraca kontekst historyczny i rodzime realia kulturowe tej produkcji, podkreślając, że film Shindō był w czasie swojej premiery kinowej określany jako opowieść ludowa (min-

filmowy 38. Japan Week (Tygodnia Japońskiego), imprezy organizowanej cyklicznie przez International Friendship Foundation, która odbyła się w dniach 19-24 października 2013 roku w Poznaniu, <http://www.zamek.poznan.pl/news,pl,26,2551.html>, dostęp: 20.10. 2013.

${ }^{3}$ Por. Tony Rayns on The Ballad of Narayama, dodatek dołaczony do wydania DVD filmu Shōheia Imamury Ballada o Narayamie w serii The Master of Cinema \#24 (dystr. Eureka!).

${ }^{4}$ J. Kapur, The Return of History as Horror: Onibaba and the Atomic Bomb, [w:] Horror International, red. Steven Schnieder, T. Williams, Detroit 2005.

5 A. Lowenstein, Unmasking Hiroshima: Demons, Human Beings, and Shindo Kaneto's Onibaba, [w:] tegoż, Shocking Representation: Historical Trauma, National Cinema, and the Modern Horror Film, New York 2005. 
wa-mono) lub film niezależny (dokuritsu-puro-eiga) i jako wybitny reprezentant tego ostatniego został zakwalifikowany do pokazów na rodzimym, corocznym festiwalu Geijutsusai, sponsorowanym przez rząd.

Zdaniem Wady-Marciano terminologia używana w filmoznawstwie zachodnim często nie jest odpowiednia do opisu kina japońskiego. Zjawiska charakterystyczne wyłącznie dla kinematografii Nipponu są określane w języku japońskim za pomocą odrębnych terminów. Według autorki rozsądniejszą i bardziej racjonalną praktyką jest objaśnianie ich w innych językach i tworzenie stosownych dla nich odpowiedników zamiast dopasowywania do nich kategorii używanych w filmoznawstwie światowym. Jak widać na przykładzie Kapur i Lowensteina, badacze, których metodologiczne kompetencje są w pewnym stopniu ograniczone do kultury Zachodu, mogą być skłonni, aby ignorować odmienność kinematografii narodowych. Jeśli preferują oni refleksję ahistoryczną, ich skłonność do esencjonalizmu może prowadzić do błędnych wniosków. Japanese Cinema in the Digital Age, podobnie jak poprzednia praca Wady-Marciano pt. Nippon Modern: Japanese Cinema of the 1920s and 1930s, została wydana w dwóch wersjach językowych - angielskiej i japońskiej - a przyjęta w nich terminologia, która dla użytkowników języka japońskiego będzie jak najbardziej zrozumiała, dla pozostałych odbiorców może okazać się często niezrozumiała i problematyczna. Muszą się oni jednak pogodzić $\mathrm{z}$ tym, że - skoro przyszło im interesować się kulturą egzotyczna - z takim też jej, egzotycznym, opisem muszą się zmierzyć.

Wada-Marciano zajmuje się w swojej pracy skomplikowaną kwestią autentyzmu cyfrowego, zjawiska szeroko obecnego we współczesnym japońskim kinie arthouse'owym. Podjęta z tej perspektywy analiza twórczości Hirokazu Kore'edy, Naomi Kawase, czy opis przypadku Nowego boga (Atarashii kamisama, reż. Yutaka Tsuchiya, 1999) ukazuje, w jaki sposób reżyserzy korzystają ze swojej wiedzy na temat psychologii odbioru nowych mediów, aby zbudować wrażenie autentyzmu (Kore'eda), konstruują własne koncepcje filmu realistycznego (riaruna eiga, Kawase), czy opierając się na tradycji kina rodzimego, tworzą w jej ramach własną wypowiedź artystyczną (jest to przypadek Tsuchiyi i związana z nim kwestia tzw. dokumentu osobistego, stylu znanego z filmów dokumentalnych kontrowersyjnego reżysera Kazuo Hary).

Kwestia realizmu filmowego i dokumentalizmu są blisko związane ze zjawiskiem swoiście rozumianego kina niezależnego, które stało się dominującym modelem w japońskiej kinematografii po tym, jak, poczynając już od lat 60. ubiegłego wieku, system studyjny uległ stopniowej dezintegracji. Wada-Marciano błyskotliwie demaskuje to, co kryje się za tym terminem - dość dwuznacznie odbieranym w kraju, w którym działalność 
niekomercyjna jest postrzegana negatywnie i traktowana $\mathrm{z}$ dużą dozą podejrzliwości ${ }^{6}$. Punktem wyjścia staje się $\mathrm{w}$ książce analiza zjawiska „osobistej” animacji, która wiąże się z problematyką tzw. nowego japońskiego niezależnego filmu animowanego. Jest to kwestia dotąd nieobecna w badaniach zachodniego filmoznawstwa, gdyż jedyną dotąd opublikowaną pracę na ten temat trudno określić mianem naukowej7. Twórczość omówionych przez Wadę-Marciano reżyserów (Mamoru Oshii, Makoto Shinkai, Kōji Yamamura) jest co prawda ceniona wśród miłośników japońskiej animacji i zachodnich krytyków, zwłaszcza w przeciwieństwie do innych artystów niezależnych (np. tych zgrupowanych wokół Studia Calf: Atsushiego Wady, Miraiego Mizue, Shina Hashimoto i innych), lecz rygor i konsekwencja stosowanego przez nią opisu wyróżnia jej pracę na tle książek i artykułów o japońskim filmie rysunkowym. Badaczka zwraca uwagę na obecny $w$ wielu pracach naukowych i popularnych terminologiczny chaos, związany $\mathrm{z}$ często błędnym umiejscawianiem anime $\mathrm{w}$ obrębie animacji japońskiej, a w zasadzie - zamiennym używaniem obu pojęć.

Choć fizyczne rozmiary pracy Mitsuyo Wada-Marciano są dość skromne, a badania japońskiej kultury audiowizualnej mogą sytuować jej rozważania na marginesach światowej myśli filmoznawczej i medioznawczej, skupionej przede wszystkim na opisie kina zachodniego, problematyka przez nią podjęta (cyfryzacja a kwestia realizmu, narodowe a transnarodowe, kino etniczne a zjawisko rasizmu) jest ważka, a przy tym często dość uniwersalna. Część spośród refleksji japońskiej badaczki można odnieść również do innych kin narodowych (co zresztą, z dużym powodzeniem, udaje jej się, gdy podejmuje temat obecnie popularnego w Polsce kina nordyckiego). Przypadek kina Nipponu, a więc kinematografii kraju, w którym rozwój i popularyzacja technologii cyfrowych znacząco wpłynął na zjawiska społeczne, prowokuje czytelnika pracy Wady-Marciano także do refleksji wychodzących poza kino dalekowschodnie.

${ }^{6}$ Problem ten omawia Sayoko Kinoshita, dyrektor Międzynarodowego Festiwalu Filmów Animowanych w Hiroshimie i autorka filmów animowanych; zob. D. Ehrlich, Memory of an Animated Couple: Renzo and Sayoko Kinoshita, [w:] Animation in Asia and the Pacific, red. J.A. Lent, Bloomington, Indianapolis 2001, s. 51-54.

7 C. Robinson, Japanese Animation: Time Out of Mind, New Barnet 2010. Specyfikę książki Chrisa Robinsona, którego do napisania tej szczególnej pracy zainspirował styl dziewiętnastowiecznej krytyki artystycznej, szczegółowo omówiłem w recenzji na portalu jFILM: <http://www.jfilm.pl/index.php/publicystyka/recenzje/351-recenzja-time-out-ofmind>, dostęp: 20.10 .2013 . 